\title{
LABORATORY TESTS IN DIAGNOSIS \\ OF MASTOCYTOSIS: LITERATURE REVIEW AND CASE REPORT \\ Aleksandra S Orlova ${ }^{1}$, Karina M Shkurlatovskaia ${ }^{1}$, Ekaterina V Silina ${ }^{1}$, Polina M Pyatilova ${ }^{1}$, Natalya P Teplyuk ${ }^{1}$, Evgeniya A Kogan ${ }^{1}$, Sergej I Vorobyev ${ }^{1}$, Stefani S Bolevich ${ }^{1}$, Valida A Dadaeva ${ }^{2}$, Bella I Tachieva ${ }^{1}$ and Sergej B Bolevich ${ }^{1}$ \\ ${ }^{1}$ I.M. Sechenov First Moscow State Medical University, Moscow, Russia \\ ${ }^{2}$ National Research Center for Preventive Medicine, Moscow, Russia
}

\section{LABORATORIJSKI TESTOVI U DIJAGNOZI MASTOCITOZE: PREGLED LITERATURE I PRIKAZ SLUČAJA}

Aleksandra S Orlova ${ }^{1}$, Karina M Shkurlatovskaia ${ }^{1}$, Ekaterina V Silina ${ }^{1}$, Polina M Pyatilova ${ }^{1}$, Natalya P Teplyuk ${ }^{1}$, Evgeniya A Kogan ${ }^{1}$, Sergej I Vorobyev ${ }^{1}$, Stefani S Bolevich ${ }^{1}$, Valida A Dadaeva ${ }^{2}$, Bella I Tachieva ${ }^{1}$ i Sergej B Bolevich ${ }^{1}$

${ }^{1}$ Prvi moskovski državni medicinski univerzitet I.M. Sechenov, Moskva, Rusija

${ }^{2}$ Nacionalni istraživački centar za preventivnu medicinu, Moskva, Rusija

\begin{abstract}
Mastocytosis is a heterogeneous group of disorders characterized by abnormal growth and accumulation of mast cells (MCs) in the skin and/or other organ systems. Mastocytosis is a rare disease. The annual incidence is 5-10 cases per 1 million people. However, the majority of cases stay undiagnosed due to the lack of specific tests and a wide variety of clinical features of the disease. In mastocytosis, somatic mutations of KIT gene lead to autocrine dysregulation and constitutive c-KIT activation in the absence of its ligand SCF. Clinical symptoms of the disease are determined by MC mediator release and/or infiltration of tissues by MCs. According to the World Health Organisation classification updated in 2016 mastocytosis is divided to cutaneous mastocytosis (CM), indolent systemic mastocytosis (ISM), smoldering systemic mastocytosis (SSM), SM with an associated hematologic (non-MC-lineage) neoplasm (SMAHN), aggressive SM (ASM), MC leukemia (MCL) and MC sarcoma (MCS). The CM and ISM prognosis is excellent with (almost) normal life expectancy, unlike aggressive forms (ASM and MCL) with poor prognosis. In this paper the key aspects of clinical features and diagnostic criteria of mastocytosis are discussed. We present a case report of a patient with mastocytosis in the skin following psoralen plus ultraviolet A (PUVA) therapy with good response.
\end{abstract}

Keywords: mastocytosis, cutaneous mastocytosis, systemic mastocytosis, case report, D816V mutation, KIT, tryptase

\section{SAŽETAK}

Mastocitoza je heterogena grupa poremećaja koju karakteriše abnormalni rast i akumulacija mastocita (MC) u koži i/ili drugim sistemima organa. Mastocitoza je retka bolest. Godišnja incidencija je 5-10 slučajeva na milion ljudi. Međutim, većina slučajeva ostaje nedijagnostikovana zbog nedostatka specifičnih testova $i$ širokog spektra kliničkih karakteristika bolesti. Kod mastocitoze, somatske mutacije KIT gena dovode do autokrine disregulacije i konstitutivne aktivacije c-KIT u odsustvu SCF liganda. Klinički simptomi bolesti su određeni oslobađanjem posrednika MC i/ili infiltracijom tkiva uz pomoć MC. Prema ažuriranoj klasifikaciji Svetske zdravstvene organizacije iz 2016. godine mastocitoza je podeljena na kožnu mastocitozu (CM), indolentnu sistemsku mastocitozu (ISM), tinjajuću sistemsku mastrocitozu (SSM), SM sa povezanom hematološkom (non-MClineage) neoplazmom (SMAHN), agresivnu SM (ASM), leukemiju MS (MCL) i MC sarkom (MCS). Prognoze CM i ISM su odlične sa (skoro) normalnim očekivanim životnim vekom, za razliku od agresivnih oblika (ASM i MCL) sa lošom prognozom. U ovom radu se razmatraju ključni aspekti kliničkih karakteristika i dijagnostičkih kriterijuma mastocitoze. Dat je prikaz slučaja pacijenta sa mastocitozom kože nakon terapije psoralenom plus ultraljubičasta A svetlost (PUVA) sa dobrim odgovorom.

Ključne reči: mastocitoza, kožna mastocitoza, sistemska mastocitoza, prikaz slučaja, mutacija D816V, KIT, triptaza 


\section{INTRODUCTION}

The term 'mastocytosis' denotes a heterogeneous group of disorders characterized by abnormal growth and accumulation of MCs in the skin and/or other organ systems (1).

This unique disease, characterized by symmetrical spread with pigmented maculopapular lesions, was for the first time described in 1869. In 1878 a term, "urticarial pigmentosa" (UP) was introduced. In 1879, Paul Ehrlich was the first to discover MCs. Later, in 1887 Paul Gerson Unna discovered that skin lesions contained focal accumulations of MCs. It was first assumed that pathologic accumulation of MCs is restricted to skin, but in 1949 a clinical case of systemic mastocytosis was described: autopsy revealed accumulation of MCs in visceral organs. In 1953, term "mastocytosis" became generally recognized (1-3).

At the 'Year 2000 Working Conference on Mastocytosis' clinical, histologic, immunologic and biochemical markers of mastocytosis were defined and criteria for the diagnosis and differential diagnosis were developed. According to WHO classification in 2001 and 2008, mastocytosis was regarded as a subgroup of myeloproliferative neoplasms. In the current revised WHO classification (2016) mastocytosis is an independent nosological entity, which is divided according to the affected organ system into cutaneous mastocytosis (CM), systemic mastocytosis (SM) and localized MC tumors $(1,4,5)$ (Table 1$)$.

\section{Diagnostic criteria for MC according to WHO}

CM is diagnosed based on a typical clinical presentation, histological evaluation of skin biopsy (typical dense multifocal MC infiltrates in derma) with no signs of SM.

Diagnosis of SM requires the presence of the following criteria: major criterion: dense multifocal MC infiltrates in a histologic and immunohistochemical evaluation of a biopsy sample of bone marrow or different extra-cutaneous organs (aggregation of > $15 \mathrm{MCs}$ ). Minor criteria confirm a neoplastic nature of the pathologic process: 1 . Cytomorphologic examination of bone marrow and/or other extra-cutaneous organs reveals $>25 \%$ of atypical MCs, 2. Presence of activating point mutation KIT D816V*, 3. MCs expressing CD2 and/or CD25*, 4. Sustained elevation of serum tryptase $>20$ $\mathrm{ng} / \mathrm{ml}$ (not valid for SM-AHNMD).* Not applicable for skin.

Table 1. Mastocytosis classification

\begin{tabular}{|c|c|}
\hline Types and subtypes & Diagnostic criteria and significant clinical signs \\
\hline \multicolumn{2}{|l|}{ I. Skin involvement. } \\
\hline Mastocytosis in the skin (MIS) & $\begin{array}{l}\text { CM criteria are fulfilled, SM not excluded because of insufficient } \\
\text { diagnostics (preliminary diagnosis) }\end{array}$ \\
\hline \multirow{4}{*}{$\begin{array}{l}\text { Cutaneous mastocytosis (CM) } \\
\text { 1) maculopapular cutaneous MC (MPCM)/ } \\
\text { Urticaria pigmentosa (UP) } \\
\text { 2) diffuse CM } \\
\text { 3) skin mastocytoma }\end{array}$} & $\begin{array}{l}\text { CM criteria are fulfilled, SM criteria not fulfilled (1-2 minor SM cri- } \\
\text { teria may be present) }\end{array}$ \\
\hline & Diagnosed predominantly in adults \\
\hline & Diagnosed predominantly in children \\
\hline & Diagnosed predominantly in children \\
\hline II. Systemic mastocytosis (SM) & $\begin{array}{l}\text { SM criteria fulfilled: } 1 \text { major }+1 \text { minor criterion or } 3 \text { minor criteria } \\
\text { Skin lesions }+/-\end{array}$ \\
\hline 1) Indolent SM (ISM) & No C-finding(s), < 2 B-findings, Skin lesions ++/- \\
\hline 2) Smoldering SM (SSM) & No C-finding(s) , $\geq 2$ B-findings, Skin lesions +/- \\
\hline $\begin{array}{l}\text { 3) SM with an associated clonal hematologic non- } \\
\text { mast cell lineage disease (SM-AHN) }\end{array}$ & $\begin{array}{l}\text { SM criteria fulfilled } \\
\text { FAB/REAL/WHO criteria fulfilled }\end{array}$ \\
\hline $\begin{array}{l}\text { 4) Aggressive SM (ASM) } \\
\text { - classic } \\
\text {-transforming into MCL (ASM-t) }\end{array}$ & $\begin{array}{l}\geq 1 \mathrm{C} \text {-finding, Skin lesions }-/+ \\
<5 \% \text { of atypical MC in bone marrow smears } \\
5-19 \% \text { of atypical MC in bone marrow smears }\end{array}$ \\
\hline $\begin{array}{l}\text { 5) Mast cell leukemia (MCL) } \\
\text { - phase with no circulating MC } \\
\text { (aleukemic) } \\
\text { - phase with circulating MC } \\
\text { (leukemic) }\end{array}$ & $\begin{array}{l}\geq 1 \text { C-finding, } \geq 20 \% \text { of atypical MC in bone marrow smears } \\
\text { Skin lesions }--l_{+} \\
\text {MC }<10 \% \text { in blood smears } \\
\text { short or absent } \\
\text { MC }>10 \% \text { in blood smears }\end{array}$ \\
\hline \multicolumn{2}{|l|}{ III. Localized mast cell tumors } \\
\hline 1) Mast cell sarcoma (MCS) & Focal malignant tumor, SM criteria not fulfilled \\
\hline 2) Extracutaneous mastocytoma* & Focal benign tumor, SM criteria not fulfilled \\
\hline
\end{tabular}

* Extracutaneous mastocytoma is excluded, as no cases are registered during the last 20 years. 


\section{Epidemiology of MC}

Mastocytosis is a rare disease. Yearly incidence is $\mathbf{5 - 1 0}$ new cases per 1 million people. Some researchers assume that real incidence is much higher, but patients with minimal symptoms often do not seek medical advice. Although mastocytosis is a sporadic somatic disease, several cases of familial mastocytosis with dominant inheritance are registered $(1,8)$.

Depending on the age of initial presentation, all cases can be divided into pediatric mastocytosis (65\%) and adult mastocytosis (35\%) (9). This classification has an important prognostic value (10). CM is more prevalent in children; in most cases all symptoms disappear during puberty (1). According to recent research, in children with small monomorphic maculopapular lesions, the disease usually undergoes progression, whereas heterogenous lesions of different size (usually large lesions) disappear without treatment before adolescence.

In adults, mastocytosis is usually characterized by lifelong systemic involvement with no spontaneous remissions (11).

\section{Clinical manifestations and prognosis of MC}

The most prevalent type among cutaneous forms of mastocytosis is maculopapular CM, which presents as intensely pigmented reddish-brown macules and/or papules $(12,13)$. Some authors state that the color of lesions depends on the proliferation of epidermal melanocytes, which express c-KIT during the regulation of melanogenesis, similar to MCs. Several studies demonstrated that KIT-mutations lead to focal albinism in humans.

In case of mastocytoma, a single elastic node sized 2-5 $\mathrm{cm}$ with smooth or creased surface is visualized. Occasionally, 3-4 nodes can be present predominantly on the neck and forearms. This subtype of mastocytosis is found only in newborns and is characterized by spontaneous regression (14).
Diffuse SM is characterized by skin erythema and thickening up to erythroderma (15).

Clinical presentation of mastocytosis is associated with uncontrolled proliferation of MCs, which depends on the degree of MCs differentiation and the production of a variety of mediators, including histamine, leukotrienes, proteases, heparin and others $(1,16)$.

In patients with mastocytosis symptoms, associated with MC mediator excretion, are present, including periodic flushing (erythema, appearing spontaneously or as a reaction to a number of triggers), itching, urticarial dermographism, positive Darier's symptom (spots get reddish and swollen when rubbing) (17). Other symptoms, associated with MC mediators include: anaphylactic reactions, recurrent syncopes, occasional hypotension, gastrointestinal distress such as diarrhea, abdominal pain, gastric ulcers and neurological and psychiatric disorders $(5,14)$.

Excessive proliferation of MCs in SM leads to visceromegaly, which can cause organ failure (Table 2). Besides, more aggressive forms of SM are associated with less skin involvement $(18,19)$.

MC can substitute other bone marrow cell lineages, which can manifest as hypo-/aplastic anemia, neutropenia, thrombocytopenia, which can lead to recurrent infections and hemorrhages (spontaneous petechia and/or bruising) $(20,21)$.

MCS is very rare and is characterized by local destructive (sarcoma-like) growth. Tumor is comprised of MCs with low differentiation. Several cases of atypical tumor locations are described, including larynx, colon with subsequent generalization of process with visceral organ and haemopoietic tissue involvement. Thus, late phase MCS may be similar to ASM or MCL (22).

Prognosis in patients with CM, ISM and SSM is usually favorable, in contrast to ASM, MCL or MCS where prognosis is usually unfavorable (1).

Table 2. Clinically significant findings in SM

\begin{tabular}{|l|l|}
\hline $\begin{array}{l}\text { B-findings } \\
\text { (B, borderline } \\
\text { 'benign') }\end{array}$ & $\begin{array}{l}\text { 1) dense multifocal infiltrates in bone marrow, with MCs }>30 \% \text { and/or total serum tryptase level }>200 \\
\text { ng/ml } \\
\text { 2) dysmyelopoiesis: hypercellular bone marrow with loss of fat cells and signs of myelodysplasia or } \\
\text { myeloproliferation of non-mast cell lineages, with insufficient criteria for SM-AHN. Blood tests are } \\
\text { normal or demonstrate non-significant consistent deviation of measures. } \\
\text { 3) Visceromegaly: hepatomegaly without liver function impairment and/or lymphadenopathy on palpa- } \\
\text { tion or visualization (lymph nodes }>2 \mathrm{~cm} \text { ) and/or splenomegaly without hypersplenism. }\end{array}$ \\
\hline $\begin{array}{l}\text { C-findings } \\
(\mathrm{C}, \text { critical) }\end{array}$ & $\begin{array}{l}\text { 1) abnormal myelopoiesis in bone marrow with cytopenia; blood samples reveal: absolute neutrophil } \\
\text { count }<1^{*} 10^{9} / \mathrm{l}, \mathrm{Hb}<100 \text { g/l, platelet count }<100^{*} 10^{9} / \text { l, without non-MC hemopoietic malignization. } \\
\text { Visceropaty: }\end{array}$ \\
$\begin{array}{l}\text { 2) hepatomegaly with liver function impairment, ascites and/or portal hypertension } \\
\text { 3) splenomegaly with hypersplenism } \\
\text { 4) malabsorption with hypoalbuminemia and weight loss as a result of MC infiltration of mucous layer } \\
\text { of digestive tract (23) } \\
\text { 5) Significant osteolysis focuses and/or severe osteoporosis with spontaneous pathologic fractures, os- } \\
\text { teosclerosis }\end{array}$ \\
\hline
\end{tabular}




\section{Laboratory tests for MC}

\section{Histologic and immunohistologic evaluation.}

Diagnosis of mastocytosis is traditionally based on the detection of dense multifocal infiltrates consisting of atypical MCs in skin, bone marrow and visceral organs.

The main criterion for the diagnostics of SM is the detection of dense multifocal infiltrates usually presented along blood vessels in a bone marrow biopsy sample. The number of MCs in aggregate should be $>15$. Cytomorphologic evaluation of bone marrow aspirate may reveal a secondary criterion of SM: $>25 \%$ of atypical MCs (fusiform cells). In this case, a diagnosis of SM is verified $(1,18,24)$.

Focal aggregates of normal MCs in bone marrow may be detected in case of reactive MC hyperplasia during parasitic infections, in case of tumors, aplastic anemia, immunocytoma or some chronic inflammatory conditions.

Apart from dense infiltrates, diffuse MC infiltration of bone marrow may be seen (mixed infiltration). In that case two variants may be distinguished:

1. disseminated MCs which do not change normal structure of bone marrow; this variant is mainly seen in ISM;

2. disseminated MCs which change normal structure of bone marrow, signs of myelodysplasia and myeloproliferation are present. This variant is mainly seen in ASM and MCL.

Another important histologic sign of SM is fibrosis and osteosclerosis of bone marrow, which are typically present in ISM and never seen in MCL (1).

\section{Cytomorphologic evaluation of bone marrow smears}

In most patients with SM, the proportion of MCs in bone marrow smears (among all cells) is $<5 \%$. This information has diagnostic value, as it makes possible to exclude MCL, in which the proportion of MCs is $\geq 20 \%$.

Other haemopoietic lineages in bone marrow smears should be evaluated to exclude SM-AHN $(1,16)$.

Cytomorphologic evaluation can reveal the following cell types $(1,25)$ :

1) Non-metachromatic blasts - signs of maturation are absent, cytoplasmatic content is low, nuclear chromatin is thin, nucleoli are seen.

2) Metachromatic blasts - high nucleoplasmic ratio, nuclear chromatin is thin, several metachromatic granules (at that stage of maturation MCs and basophils are indistinguishable).

$\mathrm{MC}$ - lineage:

3) Typical tissue MCs - round or oval cells, small or medium-sized, with centrally located round or oval nucleus, without nucleoli, cytoplasm contains a lot of metachromatic granules, less commonly cytoplasm is hypo-/degranulated, low nucleoplasmic ratio.

4) Atypical MCs type I are characterized by the presence of two or three of the following signs: (1) fusiform cells, (2) eccentric or centrally located oval nucleus, (3) hypogranulated cytoplasm with focal accumulation of granules, without signs of degranulation.

5) Atypical MCs type II - cells of different forms with bi/multilobular nucleus, of mature morphology (condensed chromatin, low nucleoplasmic ratio) or immature morphology (high nucleoplasmic ratio and thin nuclear chromatin). Nucleoli may be present, cytoplasm is usually hypogranulated, without signs of degranulation.

Pathomorphologic classification of SM (1):

1) Malignant SM: metachromatic blasts + atypical MCs of type II $>20 \%$ of all MCs in bone marrow smears.

2) Benign SM: metachromatic blasts in bone marrow smears + atypical cells of type II $<10 \%$ of all MCs. Other MCs may have typical tissue morphology or may be presented by atypical type I MCs.

\section{Laboratory findings}

Elevation of serum tryptase, namely of alpha-tryptase, which is secreted by MCs in different organs. In CM patients, tryptase levels are usually within normal limits or slightly elevated (26). In SM, tryptase levels are elevated (> $20 \mathrm{ng} / \mathrm{ml}$ ). Total tryptase levels in SM correlate with the load of neoplastic MCs. At the same time, the elevation of this enzyme is seen in different myeloid tumors. In fact, serum beta-tryptase level may temporary rise in case of allergic reaction (1, 18).

Detection of abnormal expression of CD2 and/or CD25 by MCs using flow cytometry

Cytoplasmic membrane phenotype of MCs is different from basophils and other myeloid cells. In SM, MCs express CD2 and/or CD25, which are normally expressed by T-lymphocytes and NK-cells and absent on normal MCs (1).

Detection of activating somatic point mutations of c-KIT

KIT receptor (CD117), coded by c-kit oncogene, is a tyrosine kinase with five extracellular Ig-like domains (27). The first three domains are able to bind with growth factor (stem cell factor - SCF), which activates an intracellular signaling cascade via c-KIT, promoting mitotic activity and proliferation of myeloid progenitors of MCs $(28,29)$.

Somatic point mutation in c-KIT (Asp-816 $\rightarrow$ Val or D816V) activates ligand-independent growth of neoplastic MCs (30). This mutation is found in more than $90 \%$ of adult patients with SM and in children with monomorphic CM (21, 31, 32). C-KIT Gly-839 $\rightarrow$ Lys mutation is registered in children with polymorphic CM $(33,34)$. 
KIT D816V mutation is found in most patients with ISM ( $>90 \%$ ), who are characterized by favorable prognosis (35, 36). This leads to a conclusion that there are other nonD816V KIT mutations, contributing to the pathogenesis and determining aggressive course of the disease (32, 37). In fact, several other somatic mutations in TET2, SRSF2, ASXL1, CBL, RUNX1 and RAS in patients with SM-AHN, ASM, MCL were detected $(5,24)$.

Non-KIT mutations in SM-AHN are found not only in MCs, but also in other myeloid cells, CD34-progenitor cells and sometimes in monocytes and B-lymphocytes (1, 38, 39).

However, KIT mutations are found in other neoplasms, including gastrointestinal stromal tumors, acute myeloblastosis, lymphomas and seminomas $(1,2,20)$.

In addition to the abovementioned methods, a thorough evaluation for the determination of $\mathrm{B}$ - and $\mathrm{C}$-findings is required.

\section{Treatment of MC}

At present, there are no standard treatment algorithms, as mastocytosis has a variable clinical presentation and unpredictable clinical course. Treatment is based on the clinical form and presentation. In case of MC mediator-related symptoms, antihistamines, mast cell membrane stabilizers (sodium cromolyne, ketotifen), leukotriene-receptor antagonists, corticosteroids and aspirin are recommended (40-46). In patients with risk of anaphylactic shock, these drugs are recommended for chronic administration. If immune therapy is ineffective, one should consider experimental treatment with recombinant humanized monoclonal $\operatorname{IgG} 1 \kappa$ antibodies (Omalizumab) (47). In osteoporosis, bisphosphonates are prescribed (in case of contraindications), in resistant cases therapy with RANKL inhibitors may be considered. Skin lesions demonstrate positive, but temporary response to psoralen plus ultraviolet A (PUVA)-therapy, local corticosteroids (48). In SSM, ASM “immunomodulating” anticancer agents are used, including interferon-alpha and systemic corticosteroids. In MCS, surgical treatment with subsequent radiotherapy and/or chemotherapy is performed (49).
Patient with SM-AHN demand separate treatment plans for $\mathrm{SM}$ and AHN. In some cases imatinib - a specific inhibitor of c-Kit receptor activity provides positive effect (40-44). In case of rapid disease progression, experimental chemotherapy or bone marrow transplantation should be considered.

\section{Clinical case of MC}

Patient A, 20 years old, is sick since she was 14, when she first developed urticaria pigmentosa lesions on thighs. Gradually, new skin lesions on face, trunk, upper and lower extremities developed. During the examination, generalized symmetrical polymorphic skin lesions - round reddishbrown macules and papules up to $5 \mathrm{~mm}$ in diameter with smooth surface were found (Figure 1). She was Darier's symptom positive (Figure 2). Mucous lining is not affected. An insignificant enlargement of regional neck and submandibular lymph nodes is present. Subjective complaints: itching after an exposure to different irritating stimuli (cold, heat, rubbing). Clinical, biochemical and immunochemical blood test are normal. Clinical signs of nerve system, musculoskeletal system or digestive system involvement are absent. Abdominal ultrasound did not reveal any signs of organomegaly. Pathohistological examination of skin biopsy sample revealed: non-uniform epidermal atrophy with preserved cellular and basal membrane stratification. Basal layer contains elevated number of cells with melanin granules - keratinocytes and melanocytes. Sclerosis of dermal layer with moderate lymphohistiocytic infiltration of capillaries in superficial dermal layers. Toluidine blue staining reveals individual MCs with metachromatic granules of lilac color. Conclusion: MIS (Figure 4). High-sensitive ASOqPCR for KIT D816V mutation (45) in peripheral blood cells is positive; mutant fraction is $29 \%$. Serum tryptase activity IgE (ImmunoCAP) $30.10 \mathrm{ng} / \mathrm{ml}$. Based on the clinical and laboratory findings, the patient was diagnosed with MIS. A thorough evaluation of bone marrow to exclude systemic process is planned. Treatment: desloratadine in a standard dose, topical corticosteroids, 20 sessions of PUVA-therapy. Treatment was well tolerated, no side-effects were registered. Treatment resulted in process stabilization, no new lesions are present. Subjective complains are absent (Figure 3).

Figure 1. Disseminated skin rash on legs: (A) front, (B) back
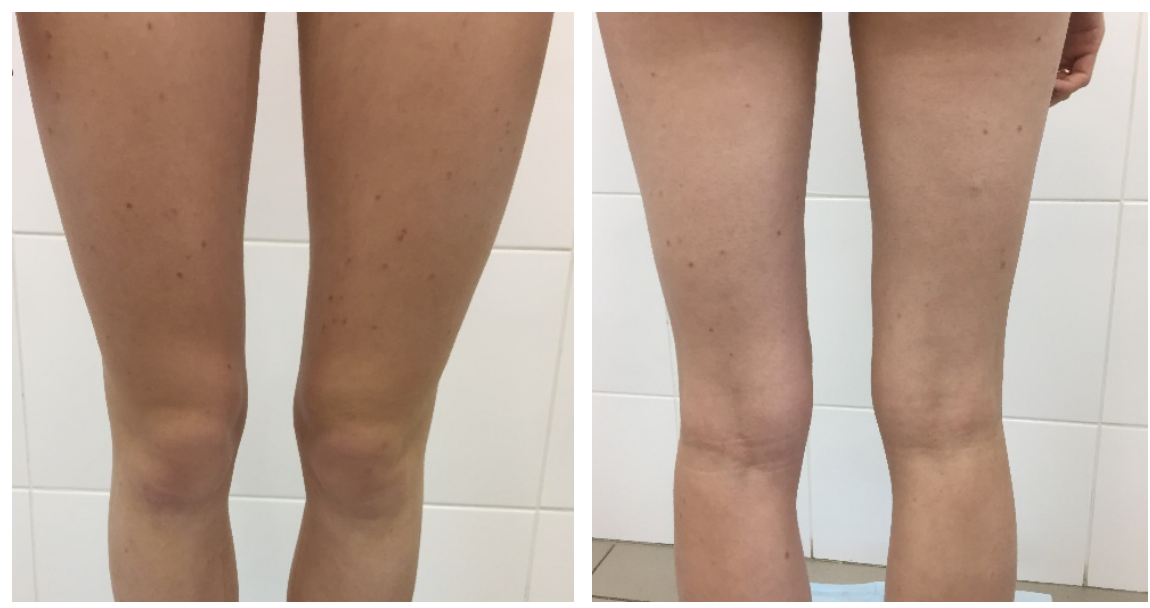
Figure 2. Darier's symptom

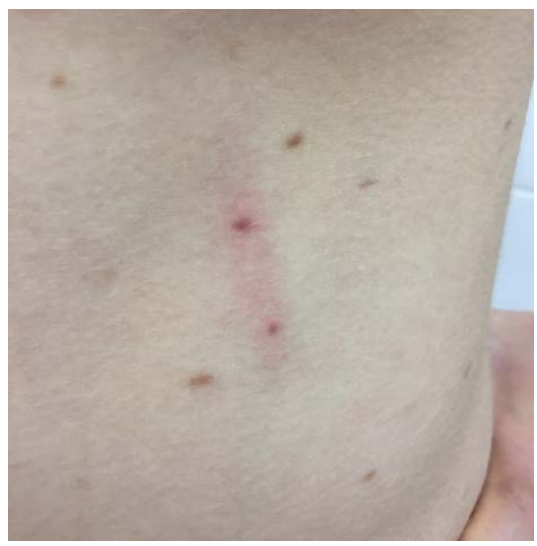

Figure 3. Disseminated skin rash on the back: before (A) and after the treatment (B)
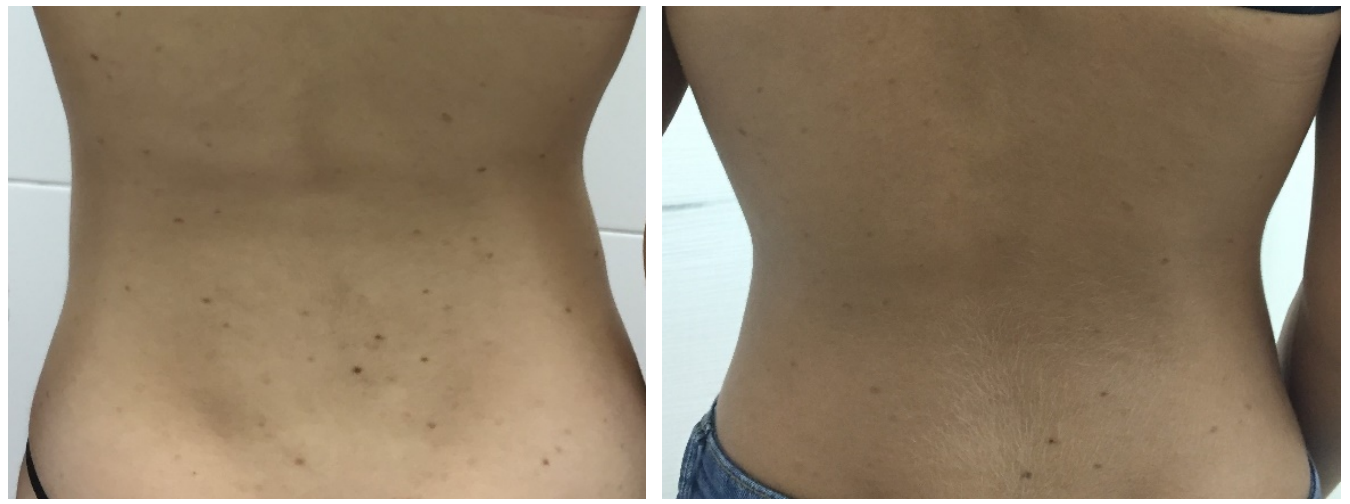

Figure 4. Skin biopsy. Hematoxylin and eosin stain (A, B), van Gieson's stain (C): increased number of cells with melanin granules in basal layer of epidermis, areas of sclerosis in derma, lymphohistiocytic infiltration around vessels. Toluidine blue staining $(\mathrm{G})$ : Isolated MCs with metachromatic granules
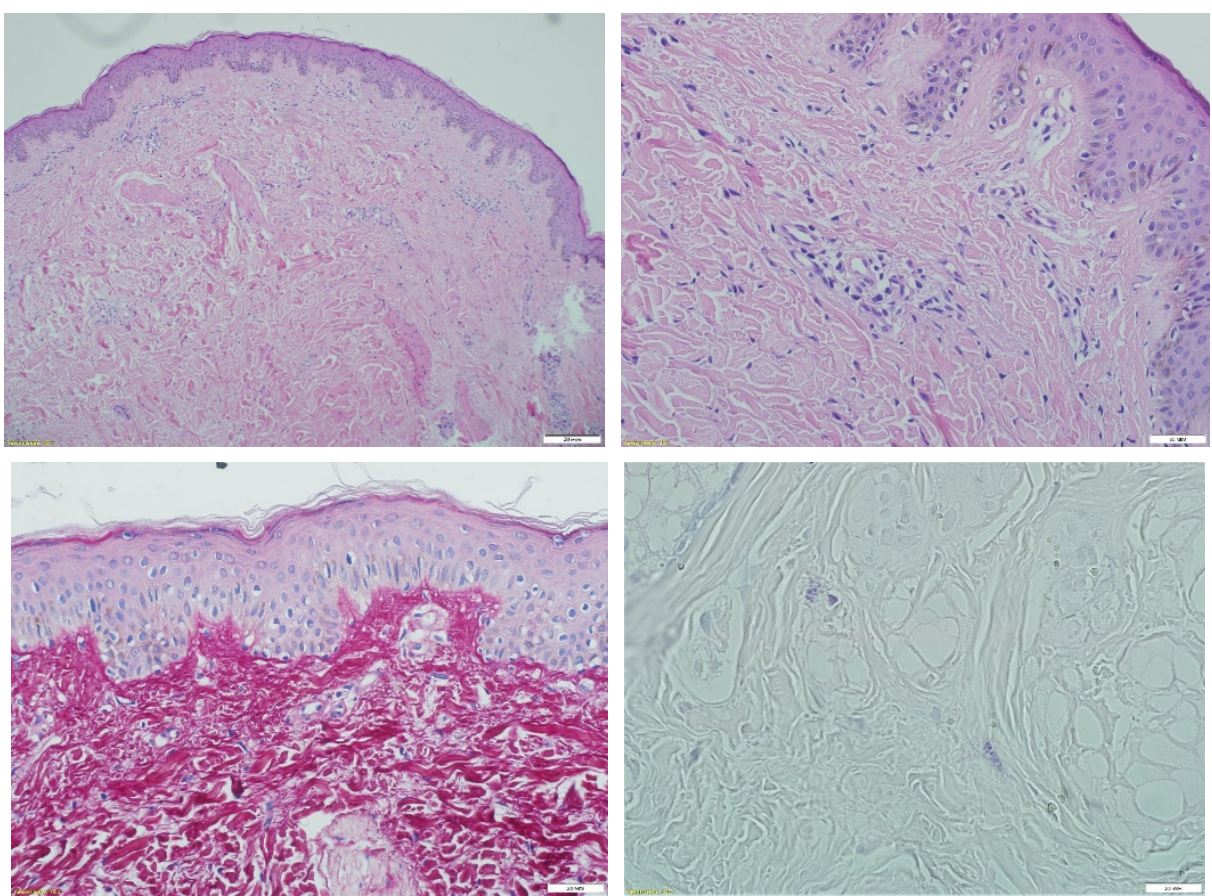


\section{REFERENCES}

1. Valent P., Horny H-P, Li CY, Longley J.B., Metcalfe D.D., Parwaresch R.M., et al. Mastocytosis (mast cell disease). In: World Health Organization (WHO) Classification of Tumours. Pathology \& Genetics. Tumoursof Haematopoietic and Lymphoid Tissues. Eds: Jaffe ES, Harris NL, Stein H, Vardiman JW. IARC PressLyon, France, 2001, pp291-302.

2. Peter Valent, Cem Akin, Karin Hartmann, Gunnar Nilsson, Andreas Reiter et al. Advances in the Classification and Treatment of Mastocytosis Current Status and Outlook toward the Future, Cancer Res; 77(6) March 15, 2017.

3. Butov J.S., Skripkin J.K., Ivanova O.L. Dermatovenereology. National guidance. Brief publication - M.: GEHOTAR-Media, 2013. - 896 pp.

4. Arber D.A., Orazi A., Hasserjian R. et al. The 2016 revision to the World Health Organization classification of myeloid neoplasms and acute leukemia. Blood. 2016; 127 (20): 2391-405

5. Peter Valent. Diagnosis and management of mastocytosis: an emerging challenge in applied hematology Hematology 2015.

6. Horny HP, Akin C, Metcalfe DD, Escribano L, Bennett JM, Valent P, et al. Mastocytosis (mast cell disease). In: Eds: Swerdlow S.H., Campo E., Harris N.L., Jaffe E.S., Pileri S.A., Stein H., et al. editors. WorldHealthOrganization (WHO) Classification of Tumours. Pathology \& Genetics. Tumours of Haematopoietic and Lymphoid Tissues. Lyon, France: IARC Press; 2008. pp 54-63.

7. ValentP, AkinC, SperrWR, HornyHP,ArockM, LechnerK, et al. Diagnosis and treatment of systemic mastocytosis: state of the art. Br J Haematol. 2003; 122: 695717.

8. Wöhrl S, Moritz KB, Bracher A et al. A c-kit mutation in exon 18 in familial mastocytosis. J Invest Dermatol. 2013; 133 (3): 839-41.

9. Nicola Wagner, Petra Staubach Mastocytosis - pathogenesis, clinical manifestation and treatment, 2018 Deutsche Dermatologische Gesellschaft (DDG). Published by John Wiley \& Sons Ltd. | JDDG

10. Valent P, Escribano L, Broesby-Olsen S et al. European Competence Network on Mastocytosis. Proposed diagnostic algorithm for patients with suspected mastocytosis: a proposal of the European Competence Network on Mastocytosis. Allergy 2014.

11. Tefferi, A. \& Pardanani, A. Systemic mastocytosis: current concepts and treatment advances. Current Hematology Reports. 2004; 3: 197-202.

12. Nagornaya N.V., Bordyugova Ye.V., Koval A.P., Dubovaya A.V. Mastocytosis in Children: Literature Review and Own Clinical Observation. Zdorov'e rebenka. 2013. № 7 (50). P. 173-177.
13. Batkaev E.A., Olenich I.V., Chistyakova I.A., Avedikian S.S., Matheopoulos R.G., Malyarenko E.N., Bobrov A.M. Mastocytosis, diagnosis and treatment. Vestnik poslediplomnogo medicinskogo obrazovaniya. 2016. № 1. C. 11-16.

14. Melikian A.L., Subortseva I.N., Goriacheva S.R., Kolosheǐnova T.I., Vakhrusheva M.V., Kovrigina A.M., Sudarikov A.B., Dvirnyk V.N., Obukhova T.N. Mastocytosis. Review of the literature and description of clinical cases. Terapevticheskij arhiv. 2014. T. 86. № 12. P. 127-134.

15. Proshutinskaya D.V., Makoveckaya O.S. Clinical features of mastocytosis at pediatric patients. Vestnik dermatologii i venerologii. 2017. № 1.P. 12-20.

16. Robyn M. Scherber and Uma Borate How we diagnose and treat systemic mastocytosis in adults. 2017 John Wiley \& Sons Ltd, British Journal of Haematology

17. Valent P, Akin C, Arock M, et al. Definitions, criteria and global classification of mast cell disorders with special reference to mast cell activation syndromes: a consensus proposal. Int Arch Allergy Immunol. 2012; 157:215-225

18. Krivolapov J.A. Bone marrow biopsy: research and practice publication. Practical medicine. 2014. -528 c. ISBN: 978-5-98811-308-9

19. Zhang LY, Smith ML, Schultheis B, Fitzgibbon J, Lister TA, Melo JV, et al. A novel K509I mutation of KIT identified in familial mastocytosis-in vitro and in vivo responsiveness to imatinib therapy. Leuk Res 2006; 30:373-8.

20. Bai CG, Hou XW, Wang F, Qiu C, Zhu Y, Huang L, Zhao J, Xu JJ, Ma DL (2012) Stem cell factor-mediated wild-type KIT receptor activation is critical for gastrointestinal stromal tumor cell growth. World J Gastroenterol 18(23):2929-2937. doi:10.3748/wjg.v18. i23.2929

21. Peter ValentMastocytosis: a paradigmatic example of a rare disease with complex biology and pathology Am J Cancer Res 2013; 3(2):159-172

22. H.-P. Horny, K. Sotlar, P. Valent Evaluation of Mast Cell Activation Syndromes: Impact of Pathology and ImmunohistologyInt Arch Allergy Immunol 2012; 159:1-5

23. Jensen RT. Gastrointestinal abnormalities and involvement in systemic mastocytosis. Hematol Oncol Clin North Am 2000; 14:579-623.

24. Horny HP, Sotlar K, Valent P. Mastocytosis: state ofthe art. Pathobiology 2007; 74:121-32.

25. Wimazal F, Sperr WR, Horny H-P, Carroll V, Binder BR, Fonatsch C, Walchshofer S, Fo"dinger M, Schwarzinger I, Samorapoompichit P, Chott A, Dvorak AM, Lechner K, Valent P. Hyperfibrinolysis in a case of myelodysplastic syndrome with leukemic spread of mast cells. Am J Hematol 1999; 61:66 -76.

26. Khantawatana S, Carias R, Arnaout R, Hu J, Irani AM, Schwartz LB. The potential clinical utility of serum alpha-protryptase levels. J Allergy Clin Immunol 1999; 103:1092-9. 
27. Lennartsson J, Ronnstrand L (2012) Stem cell factor receptor/cKit: from basic science to clinical implications. Physiol Rev 92(4): 1619-1649. doi:10.1152/physrev. 00046.2011

28. Tsibulkina V.N., Tsibiakin N.A. Pathophysiology of mast cells in mastocytosis: implications for clinics and diagnosis. Prakticheskaya medicina. 2016. № 9 (101). P. 7-11.

29. Cardet JC, Akin C, Lee MJ (2013) Mastocytosis: update on pharmacotherapy and future directions. Expert Opin Pharmacother 14(15):2033-2045. doi:10.1517/1465656 6.2013.824424

30. Akin C, Kirschenbaum AS, Semere T, Worobec AS, Scott LM, Metcalfe DD. Analysis of the surface expression of c-kit and occurrence of the c-kit Asp816Val activating mutation in $\mathrm{T}$ cells, B cells, and myelomonocytic cells in patients with mastocytosis. ExpHematol 2000; 28: 140-7.

31. Andres C. Garcia-Montero, Maria Jara-Acevedo, Cristina Teodosio KIT mutation in mast cells and other bone marrow hematopoietic cell lineages in systemic mast cell disorders: a prospective study of the Spanish Network on Mastocytosis (REMA) in a series of 113 patients The American Society of Hematology 2006

32. Bodemer C, Hermine O, Palmerini F, Yang Y, Grandpeix-Guyodo C, Leventhal PS, et al. Pediatric mastocytosis is a clonal disease associated with D816V and other activating c-KIT mutations. J Invest Dermatol 2010; 130:804-15.

33. Daniel Elieh, Ali Komi, Todd Rambasek, Stefan Wöhrl Mastocytosis: from a Molecular Point of View Clinic Rev Allerg Immunol 2017

34. Longley BJ, Metcalfe DD. A proposed classification of mastocytosis incorporating molecular genetics. Hematol Oncol Clin North Am 2000; 14:697-701.

35. Giovanna De Matteisa, Roberta Zanott The impact of sensitive KIT D816V detection on recognition of Indolent Systemic Mastocytosis Leukemia Research 39 (2015) 273-278
36. Alvarez-Twose I, Jara-Acevedo M, Morgado JM, García-Montero A, Sanchez-Mu noz L, Teodosio C, et al. Clinical, immunophenotypic, and molecular characteristics of well-differentiated systemic mastocytosis. J Allergy Clin Immunol 2016; 137:168-78

37. Georg Greiner, Michael Gurbisz Digital PCR: A Sensitive and Precise Method for KIT D816V Quantification in Mastocytosis Clinical Chemistry 64:3 (2018)

38. Akin C, Kirschenbaum AS, Semere T, Worobec AS, Scott LM, Metcalfe DD. Analysis of the surface expression of c-kit and occurrence of the c-kit Asp816Val activating mutation in T cells, B cells, and myelomonocytic cells in patients with mastocytosis. Exp Hematol 2000; 28:140-7.

39. Sperr WR, Horny H-P, Lechner K, Valent P. Clinical and biologic diversity of leukemias occuring in patients with mastocytosis. Leuk Lymphoma 2000; 37:473-86.

40. Metcalfe DD. The treatment of mastocytosis. J Invest Dermatol 1991; 96:55S-6S.

41. Marone G, Spadaro G, Granata F, Triggiani M. Treatment of mastocytosis: pharmacologic basis and current concepts, Leuk Res, this issue.

42. Turk J, Oates JA, Roberts LJ. Intervention with epinephrine in hypotension associated with mastocytosis. J Allergy Clin Immunol 1983; 71:189-92.

43. Graves L, Stechschulte DJ, Morris DC, Lukert BP. Inhibition of mediator release in systemic mastocytosis is associated with reversal of bone changes. J Bone Mineral Res 1994; 5: 1113-9.

44. Povoa P, Ducla-Soares J, Fernandes A, Palma-Carlos AG. A case of systemic mastocytosis; therapeutic efficacy of ketotifen. J Intern Med 1991; 229:475-7.

45. Horan RF, Scheffer AL, Austen KF. Cromolyn sodium in the management of systemic mastocytosis. J Allergy Clin Immunol 1990; 85:852-5. 